\title{
Urgensi ‘Urf dalam Tradisi Male dan Relevansinya dalam Dakwah Islam di Jembrana-Bali
}

\section{Urgency of 'Urf in the Male Tradition and it's Relevance in Islamic Dakwah in Jembrana-Bali}

\author{
Saihu \\ Pascasarjana Institut PTIQ Jakarta \\ Email: madesaihu@ptiq.ac.id \\ Artikel diterima 9 Juli 2019, diseleksi 19 Oktober 2019, \\ dan disetujui 10 Desember 2019
}

Abstrak: Tulisan ini membahas tentang strategi dakwah di Jembrana-Bali melalui sarana 'urf yaitu pada tradisi male. Tulisan berfokus menelusuri dampak dari strategi 'urf atau kearifan lokal terhadap proses interaksi dan integrasi yang mengarah pada praktik damai pada masyarakat Hindu dan Muslim di Jembrana-Bali. Sumber data diperoleh adalah melalui observasi dan wawancara tak terstruktur selama bulan Maret sampai Juni 2019. Tulisan ini berupa penelitian lapangan dengan menggunakan metode studi kasus. Hasil dari tulisan ini memperlihatkan bahwa dakwah Islam melalui 'urf yang mewujud dalam tradisi male dapat menumbuhkembangkan pemahaman kebhinekaan, menumbuhkan ketertarikan umat Hindu kepada Islam, serta dapat membentuk karakter masyarakat Hindu dan Muslim di Jembrana menjadi humanis, toleran, dan inklusif, sehingga mengarah pada proses asosiasi, integrasi, komplementasi dan sublimasi.

Kata Kunci: 'Urf, Dakwah, Male, Asosiasi, Integrasi, Komplementasi, Sublimasi.

Abtract: This paper discusses the da'wah strategy in Jembrana-Bali through the means of $f$ urf, namely in the male tradition. Writing focuses on exploring 
the impact of the 'urf strategy or local wisdom on the process of interaction and integration which leads to peaceful practices of Hindu and Muslim communities in Jembrana-Bali. The source of the data obtained is through unstructured observations and interviews from March through June 2019. This paper is in the form of field research using a case study method. The results of this paper show that Islamic preaching through the 'urf' which manifests in the male tradition can foster diversity understanding, foster Hindu interest in Islam, and can shape the character of Hindu and Muslim communities in Jembrana to be humanist, tolerant and inclusive, thus leading in the process of association, integration, complementation and sublimation.

Keywords: 'Urf, Dakwah, Male, Association, Integration, Complementation,

Sublimation.

\section{A. Pendahuluan}

Tulisan membahas tentang bagaimana urgensi dari 'urf yang terwejahtahkan melalui tradisi male sebagai sarana strategi dakwah islam yang inklusif pada daerah minoritas Muslim di Jembrana-Bali. Hal ini penting untuk diejawantahkan , karena 'urf yang biasa disebut "tradisi" hakikatnya sangat penting dalam penetapan hukum Islam. Menurut alQarafi, dalam berdakwah, para mujtahid harus mengenal 'urf atau tradisi suatu masyarakat lebih dahulu sebelum memberikan fatwa hukum sehingga tidak berseberangan dengan kemaslahatan umat. ${ }^{1}$ Arti penting 'urf salah satunya dapat dilihat dari apresiasi Islam atas tradisi yang telah ada pada masyarakat Arab sejak sebelum kedatangannya. Islam lahir di tengah suatu budaya dan sistem nilai, bahkan di tengah kepercayaan dan praktik keagamaan yang telah semarak. Semua itu justru menjadi miliu dan memberikan "konteks" bagi kelahiran Islam. ${ }^{2}$ Urgensi 'urf semakin terasa ketika Islam memasuki dunia non-Arab. Islam yang "terbungkus" budaya Arab berhadapan dengan budaya dan tradisi yang berbeda. Tidak jarang, para tokoh agama justru gagap melihat keragaman budaya dan tradisi luar sehingga cenderung menganggapnya sebagai "sesat" 
dan tidak islami. Yang muncul kemudian adalah anggapan bahwa Islam yang benar dan murni adalah "Islam yang bercorak Arab".

Untuk konteks Indonesia, 'urf disamakan maknanya dengan kearifan lokal. Kearifan lokal yang ada di masyarakat dapat dijadikan sebagai mekanisme sosio-kultural yang diyakini dan telah terbukti ampuh sebagai sarana dalam menggalang persaudaraan dan solidaritas antar warga yang telah melembaga dan mengkristal dalam tatanan sosial dan budaya. ${ }^{3}$ Lebih jauh, 'urf, dalam tulisan ini akan disebut sebagai kearifan lokal (lokal wisdom), dapat diartikan sebagai pandangan hidup, ilmu pengetahuan, dan berbagai strategi kehidupan yang berwujud aktivitas, dilakukan oleh masyarakat setempat untuk menjawab berbagai masalah dalam pemenuhan kebutuhan mereka.

Kendati demikian, masih banyak ditemukan pandangan yang mengecilkan arti dan peran serta kearifan lokal dalam menciptakan toleransi antar komunitas yang berbeda. Fenomena akhir-akhir ini di Indonesia, 'urf sering diabaikan dan dikalahkan oleh makna harfiah teks yang menjadi pusat rujukan penetapan hukum dengan berlindung di balik jargon kembali pada Al-Qur'an dan Sunah yang umumnya dianut oleh aliran literal konservatif atau salafi-wahabi yang memandang hukum Islam sebagai sesuatu yang rigid dan tidak bisa diubah karena berasal dari Tuhan. Padahal, melalui 'urf atau kearifan lokal, hukum Islam akan lebih bersifat kontekstual, sehingga Islam akan lebih bersifat dinamis sesuai dengan kondisi sosial kultural yang dalam perkembangan selanjutnya akan membuat hukum Islam menjadi lebih humanis. ${ }^{4}$

Menurut aliran ini, masyarakat muslim yang menjadikan kearifan lokal sebagai sarana untuk berinteraksi dengan komunitas yang berbeda agama dan budaya sering disebut sebagai kelompok sinkretis yang menggabungkan ajaran agama Islam dengan kepercayaan lain atau sebagai masyarakat yang belum menjalankan syariat Islam secara kaffah. Penghargaan mereka terhadap lingkungan alamnya disalahpahami sebagai bentuk paham yang dipengaruhi oleh animisme atau sebagai 
perbuatan syirik yang dilarang agama. ${ }^{5}$ Padahal hal ini tidaklah semuanya benar, karena kearifan lokal atau 'urf atau local wisdom adalah inti tradisi masyarakat yang "diakui" sebagai milik bersama, dinilai patut, dikenal makna positifnya, dan terbukti efektif dalam mempertahankan keberlangsungan dan keharmonisan bermasyarakat.

Tolok ukur yang harus ditetapkan dalam mempertimbangkan kearifan lokal adalah humanisasi. ${ }^{6}$ Dengan menjadikan humanisasi sebagai tolok ukur, ini berarti bahwa apresiasi terhadap kearifan lokal atau 'urf atau local wisdom mempromosikan inti ajaran agama yang bersifat universal. Bukankah tujuan utama syariat yang diformulasikan para ahli fikih berupaya untuk memelihara akal, jiwa, harta benda, kehormatan diri, dan agama, maka dengan ini kearifan lokal sangat terkait dengan humanisasi karena hal ini menyangkut perlindungan hak asasi manusia dan kebutuhan dasarnya. Humanisasi adalah ajaran dasar Islam sebagai Syariat al-rahmah, yaitu tuntunan yang memadukan antara kebenaran dan kasih sayang, antara memaafkan dan bertindak dengan makruf (mempertimbangkan kebaikan yang diakui masyarakat), antara 'azimah dan rukh'ah, antara hanifiyah dan sam'ah. ${ }^{7}$ Sejalan dengan ini, ajaran dasar Islam memberikan kemudahan manusia, memelihara kemaslahatan umum, dan memperhatikan kondisi lingkungan dimana kearifan lokal tersebut implementasikan sehingga menjadi sebuah proses pendidikan yang mengarah kepada pembentukan karakter masyarakatnya. ${ }^{8}$

Bagi masyarakat Muslim di Jembrana, strategi dakwah melalui kearifan lokal bertujuan untuk membantu dan atau menciptakan generasi dalam mengembangkan semua unsur potensi pribadinya, baik itu intelektualitas, spiritualitas, moralitas, sosialitas, maupun rasionalitas, serta dapat menguatkan solidaritas antar umat beragama, sekaligus menjawab pendekatan dakwah yang rigid sehingga pada praktiknya banyak menghilangkan nilai-nilai keunggulan budaya, agama, serta kearifan lokal yang ada di masyarakat. ${ }^{9}$ Strategi dakwah ini dimulai dari lingkungan keluarga dengan banyak menanamkan konsepkonsep, gagasan, dan nilai-nilai, serta pandangan hidup masyarakat 
Jembrana yang tertuang dalam filosofi Tri Hita Karana (tiga penyebab kesejahteraan) meliputi: Parahyangan (menjalin hubungan baik dengan Tuhan), Pawongan (menjalin hubungan baik dengan sesama manusia), dan Palemahan (menjalin hubungan baik dengan alam semesta). Pandangan hidup ini diajarkan kepada seluruh anggota keluarga yang pada tataran selanjutnya masing-masing dari mereka akan saling mengoreksi satu sama lain, apabila ada dari anggota keluarga yang tidak melaksanakan filosofi hidup tersebut. ${ }^{10}$

Begitu penting dan strategisnya nilai kearifan lokal dalam pembangunan karakter masyarakat dan bangsa, maka sangat wajar bila strategi dakwah Islam memfokuskan kajiannya pada penggalian nilainilai kearifanlokal yang hidup di dalam masyarakat dan budaya Indonesia yang ber-bhinneka tunggal ika. ${ }^{11}$ Karena sebagaimana diketahui, bahwa tradisi dan budaya yang terdapat dalam kearifan lokal, berperan penting dalam pengembangan kepribadian generasi muda yang dalam setiap tradisi tersebut terdapat nilai-nilai perenial yang unggul.

\section{B. Metodologi}

Penelitian ini adalah penelitian lapangan (field research), yang sering digunakan secara bersamaan dengan studi etnografi, ${ }^{12}$ yaitu bersifat eksploratif, bertujuan untuk memperoleh gambaran tentang pelaksanaan aktivitas tradisi male sebagai sarana dakwah yang ter-aktualisasi dengan baik dalam aktivitas kehidupan sehingga dapat menanamkan karakter inklusif pada masyarakat Jembrana sehingga tercipta kerukunan antar umat beragama khususnya umat Hindu dan Muslim. Penelitian ini dimulai dari bulan Maret sampai dengan Juni 2019 di wilayah Kabupaten Jembrana Provinsi Bali yang secara spesifik penelitian ini memfokuskan observasinya pada bagaimana dimensi humanis, pluralis, dan toleran, teraktualisasi dalam aktivitas tradisi male sebagai sarana berdakwah serta untuk memperkokoh hubungan yang harmonis antara kedua umat beragama. 
Untuk tujuan ini, maka penelitian ini lebih tepat menggunakan pendekatan kualitatif. Sebab dalam penelitian kualitatif, peneliti mengkaji sesuatu dalam setting natural dan menafsirkan fenomena terkait dengan makna. Penelitian kualitatif sebagaimana yang dikatakan oleh Sharan B. Merriam, memiliki empat karakteristik utama yaitu: 1) menekankan pada proses, pemahaman, dan makna; 2) peneliti berfungsi sebagai instrumen utama dalam pengumpulan dan analisis data; 3) proses bersifat induktif; dan 4) hasilnya bersifat deskripsi yang kaya. ${ }^{13}$

Berbeda dengan penelitian kuantitatif yang mengambil jarak antara peneliti dengan subjek penelitian, penelitian kualitatif menyatu dengan situasi objek yang diteliti (personally involved with research participants, to the points of sharing perspective). ${ }^{14}$ Selain itu, Lincoln dan Guba mengidentifikasi beberapa perbedaan aksioma pada penelitian kualitatif yang relevan dengan penelitian ini meliputi:

a. Sifat Realitas

Penelitian kualitatif berlandaskan pada filsafat post-positivisme atau paradigma interpretive. Yaitu suatu realitas atau objek tidak dapat dilihat secara parsial dan dipecah ke dalam beberapa variabel. Penelitian kualitatif memandang objek sebagai sesuatu yang dinamis, hasil konstruksi pemikiran dan interpretasi terhadap gejala yang diamati, serta utuh (holistic) karena setiap aspek dari objek itu mempunyai suatu kesatuan yang tidak dapat dipisahkan.

b. Hubungan Peneliti dengan Yang Diteliti

Dalam penelitian kualitatif, peneliti berfungsi sebagai human instrument melalui teknik pengumpulan data participant observation (observasi berperan serta) dan juga in depth interview (wawancara mendalam), maka peneliti harus berinteraksi dengan sumber data. Dengan demikian peneliti kualitatif mengenal betul orang yang memberikan data.

c. Hubungan Antar 
Dalam penelitian kualitatif yang bersifat holistik dan lebih menekankan pada proses, maka penelitian kualitatif dalam melihat hubungan antar variabel pada objek yang diteliti lebih bersifat interaktif yaitu saling mempengaruhi (reciprocal/ interaktif).

d. Kemungkinan Generalisasi

Penelitian kualitatif tidak melakukan generalisasi, tetapi lebih menekankan kedalaman informasi sehingga sampai pada tingkat makna. Walaupun penelitian kualitatif tidak membuat generalisasi, tidak berarti hasil penelitian kualitatif tidak dapat diterapkan di tempat lain. Generalisasi dalam penelitian kualitatif disebut dengan transferability (keteralihan). Maksudnya adalah bahwa, hasil penelitian kualitatif dapat ditransfer atau diterapkan di tempat lain, manakala kondisi tempat lain tersebut tidak jauh berbeda dengan tempat penelitian. ${ }^{15}$

Adapun metode yang digunakan dalam penelitian ini adalah metode studi kasus. Sebagai salah satu varian dalam penelitian kualitatif, studi kasus memberikan uraian dan penjelasan komprehensif mengenai suatu setting tertentu, dokumen, atau suatu kejadian tertentu. ${ }^{16}$ Dengan mempelajari secara maksimal mengenai hal ini, peneliti ingin mendapatkan pandangan yang lengkap dan mendalam mengenai aktualisasi tradisi Male di Jembrana. Kelebihan dari metode studi kasus sebagaimana diungkapkan oleh Lincoln dan Guba, adalah berikut:

a. Studi kasus merupakan sarana utama bagi peneliti emik, yakni menyajikan pandangan subjek yang di teliti;

b. Studi kasus menyajikan uraian menyeluruh pada apa yang dialami dalam kehidupan sehari-hari;

c. Studi kasus merupakan sarana efektif untuk menunjukkan hubungan antara peneliti dan responden;

d. Studi kasus memungkinkan untuk menemukan konsistensi internal yang tidak merupakan konsistensi gaya dan konsistensi 
faktual, tetapi juga keterpercayaan (trust-worthiness);

e. Studi kasus terbuka bagi penilaian atas konteks yang turut berperan bagi pemaknaan dalam konteks tersebut. ${ }^{17}$

Selanjutnya teknik pengumpulan data dalam penelitian ini dilakukan dengan cara observasi, in-depth interview, dan dokumentasi dari dua komunitas yaitu Hindu dan Muslim. Observasi, yaitu: mengamati secara langsung aktivitas tradisi male sebagai sarana dakwah dan interaksi antara komunitas Hindu dan Muslim di wilayah Jembrana. Observasi ini diarahkan untuk memahami setting of strategy serta kondisi sosial masyarakatnya. Begitu juga dengan memahami kondisi sosiologis masyarakat sebagai wadah pendidikan karakter terjadi di tengah masyarakat, serta memahami kemungkinan-kemungkinan terjadinya konflik sosial yang bisa jadi disebabkan oleh pemahaman teologis yang berbeda di Jembrana.

Teknik selanjutnya adalah wawancara mendalam (in-depth interview). Melalui teknik ini, banyak hal yang diperoleh dari informan. Teknik wawancara tak terstruktur merupakan teknik wawancara yang dipilih dalam penelitian ini. Menurut Deddy Mulyana, teknik wawancara tak terstruktur, memungkinkan informan dapat mendefinisikan diri dan lingkungannya dengan menggunakan istilahnya sendiri yang tentu saja berdasarkan kultur dan tradisi yang mereka anut. ${ }^{18}$

Dalam menganalisis data, penelitian ini mengacu pada prosedur analisis data Milles dan Hubermen. Menurut Milles dan Hubermen, analisis data dalam penelitian kualitatif, secara umum dimulai sejak pengumpulan data, reduksi data, penyajian data, dan penarikan kesimpulan atau verifikasi. Unsur-unsur metodologi dalam prosedur ini sekaligus mencerminkan komponen-komponen analisis yang bersifat interaktif. ${ }^{19}$ Kegiatan analisis selama pengumpulan data dimaksud untuk menetapkan fokus di lapangan, menyusun temuan sementara, pembuatan rencana pengumpulan data berikutnya, pengembangan pernyataan-pernyataan analitis dan penetapan sasaran-sasaran data 
berikutnya. Kemudian dari pengumpulan data (data collection) tersebut, direduksi (data reduction) sebagai upaya pemilihan pemusatan perhatian pada penyederhanaan, dan meng-abstrakkan data-data lapangan.

Dalam proses reduksi data, peneliti melakukan pemilihan atau pemetaan dengan membuat kategori-kategori berdasarkan permasalahan yang diteliti. Setelah hasil dari seperangkat reduksi, maka langkah selanjutnya adalah, menyajikan sekumpulan informasi atau data yang disusun, kemungkinan adanya penarikan kesimpulan. Kesimpulankesimpulan juga di verifikasi selama kegiatan penelitian berlangsung di lapangan, sehingga akan jelas bagaimana karakteristik data tersebut secara valid.

\section{Pembahasan}

\section{Potret Kehidupan Beragama Hindu dan Muslim di Jembrana}

Dari 321.008 Jiwa penduduk Jembrana, 231.707 atau sekitar 72.18\% beragama Hindu, kemudian disusul umat Islam dengan jumlah penduduk 81.329 jiwa atau $25.34 \%$, menyusul ketiga umat Kristen yang berjumlah 4.090 jiwa atau 1.27\%, lalu Katolik berjumlah 2.786 jiwa atau $0.87 \%$ Budha 1.069 jiwa, atau $0.33 \%$ Konghucu 15 jiwa, atau $0.00 \%$ dan aliran kepercayaan 12 jiwa atau $0.00 \% .{ }^{20}$ Dari data-data tersebut, terlihat Jelas bahwa umat Hindu adalah umat yang mayoritas menjadi penduduk Jembrana kemudian disusul oleh umat Muslim.

Relasi harmonis antara kedua umat beragama ini (Hindu dan Muslim) banyak dipengaruhi oleh sejarah awal kedatangan umat Muslim di Jembrana. Menurut Dhurorudin Mashad, cikal bakal komunitas Muslim di Jembrana ternyata sudah sangat tua usianya. Dia membagi penyebaran masuknya Islam di wilayah Jembrana ke dalam dua tempat dan waktu, yaitu: Pertama, komunitas Muslim kuno di Desa Baluk. Eksistensi muslim di Jembrana sudah ada menyusul runtuhnya Kerajaan Majapahit oleh penyerangan Demak Islam pada tahun 1518. Seiring dengan peristiwa itu, pelan tapi pasti, beberapa kerajaan vassal Majapahit semakin banyak 
yang mendeklarasikan diri sebagai penganut Islam. Akibat realitas yang menggejala tersebut, para Raja Majapahit terkonversi menjadi Muslim terutama di tanah Jawa. Sementara para tokoh agama, pejabat negara, dan atau pangeran yang tidak mau menerima Islam, memilih mengungsi ke berbagai wilayah lain di Nusantara.

Seiring dengan proses Islamisasi di tanah Jawa, Roro Anteng dan Joko Seger dengan para pengikutnya, mengungsi ke lereng Gunung Bromo, sehingga anak keturunan mereka kini lebih dikenal sebagai suku Tengger (singkatan dari kata gabungan Anteng dan Seger). Namun jumlah yang lebih banyak justru memilih meninggalkan Jawa menuju Bali, termasuk di antaranya Pangeran Wilis dan Pangeran Sepuh asal Blambangan. Peristiwa pengungsian Pangeran Wilis dan Pangeran Sepuh inilah yang ternyata justru dan sekaligus menjadi pangkal eksistensi komunitas Muslim di daerah Jembrana.

Mengungsinya kedua pangeran ini ditemani oleh kerabat dan para pengikutnya yang berjumlah \pm 40 orang. Sesampainya di Bali, kedua pangeran ini datang ke Pura Jati dengan membawa patung sakti sebagai oleh-oleh untuk Raja Jembrana. Kedua pangeran kemudian melanjutkan perjalanan untuk menghadap Raja Mengwi, karena Kerajaan Jembrana saat itu memang berada dibawah kedaulatan Kerajaan Mengwi. Sebelum berangkat, keduanya diiringkan raja bersama seorang abdi dekat raja bernama Pan Tabah yang ditugaskan untuk terus mendampingi pangeran. Kepada kedua pangeran itu, Raja Jembrana berpesan agar segera melapor bila sampai di Mengwi dan apabila mengalami masalah. Ternyata, sesampainya kedua pangeran tersebut di Kerajaan Mengwi, mereka ditangkap, bahkan Pangeran Sepuh dibunuh. Sementara Pangeran Wilis dan Pan Tabah berhasil lolos dan kembali ke Kerajaan Jembrana.

Pangeran Wilis hendak pulang ke Jawa tetapi tidak diperkenankan oleh keluarga kerajaan. Kelurga Kerajaan Jembrana menghadiahkan sebidang tanah di Desa Banyubiru (sekarang Baluk) di bawah pohon beringin yang besar. Lalu di lokasi inilah Pangeran Wilis dan pengikutnya 
membangun pemukiman dan untuk memudahkan persembahyangan, Pangeran Willis membangun sebuah pura yang selanjutnya pura tersebut dikenal dengan nama Pura Majapahit.

Hal yang cukup unik di sini adalah bahwa diantara pengikut setia Pangeran Wilis, ternyata ada yang sudah memeluk agama Islam sejak dari Jawa. Meski berbeda agama, tetapi abdi yang beragama Islam tersebut tetap setia mendampingi tuannya. Walhasil, untuk menghormati pengiring setianya itu, Pangeran Willis mendirikan juga sebuah masjid di sebelah barat pura dengan nama Masjid Majapahit. Dan mereka itulah yang selanjutnya menjadi cikal bakal komunitas Muslim di Desa Baluk. ${ }^{21}$

Melihat adanya perbedaan keyakinan diantara para pengikutnya, maka Pangeran Wilis membuat perjanjian tentang toleransi antar umat beragama di lokasi barunya itu. Untuk menghormati umat Islam, dalam setiap persembahyangan di pura, tidak perkenankan menggunakan sarana babi untuk hidangan dan cukup diganti dengan itik. Aturan ini terus diikuti secara turun menurun dan hingga kini. Bahkan tidak ada yang berani untuk melanggarnya. Sampai sebelum tahun 1965, komunitas Muslim di sekitar Pura Majapahit, ikut bergabung dalam upacara di pura meskipun sekadar untuk penghormatan. Agar keberadaannya tidak menganggur dan bengong (melamun), umat Islam dilibatkan untuk mekidung, yaitu kidung rengganis (dari Jawa), sedangkan umat Hindu mekidung mergasari. Namun seiring dengan bertambahnya kesadaran akan purifikasi Islam termasuk pada komunitas Muslim Banyubiru, maka komunitas Muslim tidak lagi terlibat dalam persembahyangan, akan tetapi tetap terlibat dalam pengamanan dan persiapan kegiatan upacara di pura. ${ }^{22}$

Kedua, Komunitas Muslim kampung kuno Loloan dan Air Kuning. Komunitas Loloan. ini merupakan keturunan dari suku Bugis-Makasar dan Melayu (Kuala Terengganu) yang sudah beberapa abad lalu bermigrasi ke Bali. ${ }^{23}$ Keberadaan komunitas Muslim ini juga merupakan bukti historis, bahwa Islam sudah lama masuk di wilayah Jembrana dengan mempertahankan agama Islam dan adat-istiadat Makasar serta 
Melayu. Asal-usul dari komunitas Muslim Loloan dan Air Kuning di Jembrana adalah orang-orang yang ber-etnis Makasar. Mereka datang dalam dua tahap, Pertama, tahun 1653-1655; Kedua, tahun 16601661 menyusul berakhirnya perang Makasar antara kerajaan Gowa melawan VOC yang di pimpin oleh Daeng Marewa. Suku Bugis-Makasar ini umumnya merupakan pelarian setelah adanya perjanjian bongaya pada saat Kerajaan Gowa kalah perang dengan Belanda.

Menurut KH. Ahmad Damanhuri, pelarian asal Sulawesi Selatan itu memang terus dikejar-kejar serdadu VOC (armada Speelman) dan armada Arung Palaka, karena sebagian perahu sisa eskadron BugisMakassar, masih memiliki senjata meriam. Kala itu, VOC kepada masyarakat sengaja membangun image negatif, bahwa kaum pelarian itu adalah perompak, karena mereka memang kerap melakukan serangan terhadap kapal-kapal VOC. Bahkan setelah Makasar jatuh di tahun 1667, Belanda membuat sayembara, bahwa Belanda akan memberikan hadiah sebesar 10.000-ringgit bagi siapa saja yang dapat menangkap eskadron (perahu-perahu) keturunan Sultan Gowa (berjumlah 4 buah) yang disebut Iinun alias perompak. ${ }^{24}$

Pada Tahun 1669, Daeng Nahcoda dan pengikutnya mendarat di Air Kuning lalu memasuki Kuala Perancak serta tinggal untuk sementara waktu di lokasi yang disebut Kampung Bali. Peninggalannya sampai kini masih ada, berupa sumur yang jernih yang oleh warga disebut sumur bajo. Akhirnya mereka diberi izin oleh Raja Jembrana, yakni marga Arya Pancoran (Gusti Ngurah Pancoran) untuk menetap. Tempat mereka itu kini dikenal sebagai pelabuhan Bandar Pancoran (pelabuhan lama di Loloan Barat).

Eksistensi kaum pengungsi ini pada kenyataannya tidak menjadi beban bagi warga Jembrana, justru menjadi berkah. Banyak di antara kaum Bugis ini menjadi kekuatan keamanan utama (prajurit), serta berhasil membangun perekonomian baru berupa pelabuhan. Berkat perahu-perahu pedagang jelmaan eskadron keturunan Sultan 
Gowa tersebut, Jembrana akhirnya menjadi wilayah yang tidak lagi terisolir dari dunia luar. Realitas ini menyebabkan hubungan antara kaum Bugis-Makasar (selanjutnya disebut Bugis) dan puri menjadi akrab. Apalagi Daeng Nachoda dan penembak-penembak meriam Bugis, menjadi tulang punggung kekuatan Jembrana, terutama ketika I Gusti Ngurah Panji Sakti (1680), Raja Den Bukit yang berasal dari utara Pulau Bali (Singaraja-Buleleng) menyerang Jembrana. Jembrana memang kalah, dan menjadi kerajaan vassal Buleleng, namun dukungan kaum Muslim ini tidak pernah pudar, bahkan tetap tertancap kuat dalam benak keluarga puri.

Pada tahun 1799, datang juga iring-iringan perahu pimpinan Syarif Abdullah al-Qadri (syarif tua) yang tak lain adik dari Sultan Pontianak, Syarif Abdurrahman al-Qadry. Kala itu, Sultan Pontianak takluk dari Belanda (1799). Dan Syarif Abdullah al-Qadry, tidak terima akan realitas terebut, maka ia meneruskan perlawanan di lautan serta berpetualang dengan membawa eskadron bersenjata meriam. Satu perahu menetap di Lombok Timur, sisanya sampai di Air Kuning Jembrana. Ketika menyusuri sungai Ijo Gading ke utara menuju shah bandar, Syarif Abdullah al-Qadri memberi aba-aba pada anak buah dengan bahasa Kalimantan, Liloan (tikungan), sehingga kampung di sekitarnya lantas diberi nama Loloan hingga sekarang.

Syarif Abdullah al-Qadri mengadakan kesepakatan dengan umat Islam di Jembrana-jika berdasarkan aturan kerajaan, seluruh meriam sebenarnya harus diserahkan ke raja seperti telah dilakukan kaum Bugis yang telah datang lebih dulu setelah perang Makasar-Tetapi Syarif Abdullah al-Qadry, menawarkan cara lain, yakni meriam tetap dikuasai sendiri, tetapi akan digunakan untuk membela Kerajaan Jembrana. Kesepakatan ini pun dicapai dan kaum Islam asal Kalimantan ini dipersilahkan tinggal di kanan kiri tebing sungai Ijo Gading seluas 80 hektare di sebelah utara Bandar Pancoran. Syarif Abdullah al-Qadri membuat perkampungan di sebelah timur sungai yang kini disebut Loloan Timur. Di tempat baru ini, Syarif Abdullah al-Qadry yang 
kemudian dikenal dengan nama Syarif Tua, menjadi pemimpin spiritual, di dampingi oleh Mahbubah (penghulu), Abdul Hamid (khatib), Amsyik (perbekel), dan Tahal (panglima pasukan). Kapal-kapal perang yang mereka miliki kemudian diubah menjadi kapal perniagaan, bahkan pernah menjelajah sampai ke Singapura.

Dua ekspedisi (Bugis dan Pontianak) di atas, merupakan gelombang kedua kedatangan Islam di Jembrana. Kedatangan dua kelompok Muslim ini disambut baik Raja Jembrana. Ada beberapa alasan mendasar kenapa dua kelompok umat Islam ini diterima dengan tangan terbuka: Pertama, eksistensi umat Islam di Jembrana yang telah ada ternyata mampu menjalin hubungan baik dengan komunitas Hindu; Kedua, umat Islam yang telah ada di Jembrana terbukti mampu menjadi tenaga pasukan atau prajurit yang sangat diandalkan serta memiliki loyalitas tinggi. Terbukti ketika Puri Jembrana hancur dan keluarga raja mati dihantam oleh banjir bandang, komunitas Islam tidak sertamerta membangun sebuah kerajaan sendiri. Mereka bahkan membantu pembangunan puri baru yang dibantu oleh Raja Mengwi; Ketiga, realitas menceritakan, bahwa umat Islam memiliki jasa luar biasa dalam pengembangan pelabuhan perniagaan yang memiliki pengaruh sangat positif bagi kemajuan kerajaan; Keempat, kala itu Blambangan telah dikuasai Belanda, sehingga dapat mengancam pula keamanan bahkan masa depan Jembrana. Walhasil, kehadiran para pelarian asal Sulawesi dan Kalimantan yang semuanya bekas pasukan kerajaan tentunya dapat menambah kekuatan kerajaan.

\section{Strategi Dakwah Islam melalui Tradisi Male}

Terdapat sebuah kaitan yang erat antara budaya dan tradisi yang berkembang di tengah masyarakat Jembrana sebagai solusi pengokohan kerukunan umat beragama, salah satunya adalah tradisi male. Tradisi male berasal dari tradisi umat Islam di Jembrana. Sekalipun tradisi male merupakan tradisi yang berasal dari Islam, namun dalam pelaksanaannya selalu melibatkan umat Hindu. Perbedaan agama tidak menjadi 
penghalang dalam pelaksanaan tradisi ini, karena memang umat Islam di Jembrana sangat terbuka terhadap keanekaragaman. Meminjam istilah dari Azyumardi Azra, umat Islam Jembrana bisa dikatakan sebagai “Islam with a smiling face" yaitu Islam yang penuh damai, moderat, sehingga tidak ada masalah dengan modernitas, demokrasi, HAM, perbedaanperbedaan agama, budaya, dan kecenderungan-kecenderungan lain di dunia modern..$^{25}$

Tradisi Male merupakan bentuk ritual keagamaan yang dilakukan oleh setiap keluarga dan masyarakat Muslim di Jembrana, yaitu ketika masyarakat Muslim Jembrana memperingati Maulid Nabi Muhammad Saw. Maulid Nabi dan male merupakan satu kesatuan yang tidak dapat dipisahkan dalam aktivitas ritual-nya bagi masyarakat Jembrana. Male adalah telur yang direbus dengan tidak mengupas (menghilangkan kulit luar) yang dirangkai sedemikian rupa dalam berbagai bentuk yang memiliki nilai estetika dan filosofi keagamaan yang tinggi. Bentuk male ada yang berupa "pajegan" atau bentuk lainnya dengan menusukkan puluhan telur rebus ke batang pohon pisang yang dihiasi kertas warna warni, ada juga yang menyerupai kapal-kapalan, pepohonan (bonsai), dan binatang unta. Rangkaian atau bentuk telur ini, oleh masyarakat Muslim Jembrana disebut dengan male. Male juga biasanya dijadikan bingkisan (berkat) bagi umat maupun undangan yang hadir. Apalagi dalam keluarga itu ada kelahiran, maka dalam "menyelamati" bayi yang baru lahir tersebut wajib menghadirkan male sebagai ucapan syukur kepada Allah Swt.

Menurut KH. Sya'rani Yasin, Pengasuh Pondok Pesantren Darussalam Pengambengan, istilah "male" terambil dari Bahasa Arab "mâla-yamîlumailan" yang berarti cenderung, condong, miring, memihak ke. Jadi awalnya dia disebut dengan "mala", karena lidah atau dialek orang Bali yang biasa mengganti bunyi huruf "a" menjadi " $\mathrm{e}$ ", maka istilah yang tadinya "mala" berubah menjadi "male". Yasin menambahkan bahwa rasa cinta yang besar kepada Nabi Muhammad Saw inilah yang membuat umat Islam di Bali memiliki kecenderungan dan "keberpihakan" yang 
tinggi untuk memperingati hari lahir Nabi Muhammad Saw yang kemudian mempersonifikasikan rasa cinta tersebut dengan telur yang dihias dan diberi nama male. Dia menuturkan bahwa banyak jamaah yang mengikuti acara peringatan Maulid Nabi Muhammad Saw akan merasa "sedih", dan atau kecewa jika tidak mendapatkan telur (male) dari peringatan Maulid Nabi Muhammad Saw tersebut, sekalipun mereka sebenarnya dengan mudah bisa membeli telur yang lain di toko-toko atau di warung-warung setempat. Ini berarti bahwa, rasa cinta dan kecenderungan yang memuncak dari peringatan Maulid Nabi Muhammad Saw bisa membuat sesuatu yang tadinya biasa menjadi luar biasa, dalam hal ini telur yang memiliki arti biasa-biasa saja, dia akan menjadi istimewa jika terlur tersebut sudah berubah nama menjadi male. ${ }^{26}$

Ritual male dimulai dengan berkeliling kampung sambil membawa telur yang telah dibentuk dengan berbagai corak atau sesuai dengan selera yang diinginkan pembuatnya seperti pura, perahu, masjid, rumah, bonsai dan lain-lain. Dalam aktivitas dakwah Islam, umat Islam Jembrana-Bali, meminta umat Hindu untuk bersama-sama mengarak Male mengelilingi kampung. Ketika mengarak male tersebut, umat Hindu menggunakan pakaian adat Bali yang di sebut pager uyung (pakaian kaum kesatria adat yang diwakili oleh beberapa orang dari umat Islam maupun Hindu). Dalam perjalanannya mengelilingi kampung, male yang diarak diringi dengan pembacaan asrakal, yaitu membaca solawat serta puji-pujian kepada Nabi Muhammad Saw. sambil menabuh rebana atau marawis.

Setelah selesai mengelilingi kampung, kemudian seluruh male atau telur yang telah dihiasi tersebut, dikumpulkan di dalam masjid sambil diiringi bacaan solawat. Telur yang dihiasi dan diwarnai, lalu ditusuk bambu kemudian ditancapkan ke pohon pisang sehinga terlihat pohon pisang berbuah telur ( pajegan) yang dipajang saat maulid. Setelah seluruh male dipajang, para jamaah bersenandung solawat secara berjamaah dilanjutkan dengan membaca syair solawat diba' yang berisi tentang sejarah hidup Nabi Muhammad Saw. sebagai tanda pengungkapan rasa cinta mereka kepada Nabi Muhammad Saw. ${ }^{27}$ Selanjutnya pembacaan doa 
menjadi acara penutup sebelum telur-telur dibagikan kepada masyarakat yang hadir di sana. Ketika telur dibagikan masyarakat sangat antusias untuk mendapatkan male, walau harus berdesak-desakan dan berebut, mereka percaya bahwa mereka akan mendapat berkah serta keselamatan dari male yang telah didoakan oleh para ulama atau rohaniawan tadi. ${ }^{28}$

Tradisi memperingati Maulid Nabi Muhammad Saw. dengan male, menjadi sebuah tradisi di Jembrana yang sudah berlangsung selama berabad-abad yang memiliki makna-makna edukatif-filosofis, antara lain: Pertama, telur yang sudah direbus dan diwarnai diletakkan di tempat (ember) plastik atau bakul kemudian ditutup daun pisang, sebagiannya lagi ditancapkan di batang pohon pisang. Tradisi ini merupakan strategi dakwah Islam yang hakikatnya mengandung makna-makna filosofis. Analogi-nya adalah "ayam berasal dari telur dan telur berasal dari ayam". Analogi ini bermakna bahwa telur mengingatkan setiap manusia kalau hidup itu ada awal dan akhir. Jika dilihat dari bentuknya, telur terdiri atas tiga fase, meliputi kulit telur, putih telur, dan kuning telur. Jika dihubungkan dengan kehidupan manusia, fase kulit telur dimaknai sebagai lahir, fase putih telur sebagai hidup, dan fase terakhir yaitu kuning telur sebagai akhir kehidupan.

Dengan nada yang secara eksplisit serupa, Rifqil Halim, ${ }^{29}$ menjelaskan, bahwa kulit telur merupakan simbol Iman, putih telur simbol Islam, dan kuning telur merupakan simbol Ihsan. Putih telur juga melambangkan kesucian dan keagungan, sementara kuning telur melambangkan keemasan, dan warna-warna lain seperti merah dan biru yang mewarnai kulit telur saat maulid sebagai lambang kegembiraan. Jadi telur yang ditusuk saat maulid melambangkan bahwa Iman, Islam, dan Ihsan, harus disatukan dan ditegakkan ke atas berdasarkan kalimat tauhid "lâ ilâha illallâh muhammad rasûlllâh". Telur yang ditusuk bambu melambangkan adanya kelurusan, kekuatan, dan keteguhan, layaknya pohon bambu yang tumbuh menjulang tinggi. Walhasil, berangkat dari tradisi male pada maulid Nabi Muhammad Saw. diharapkan menanamkan karakter bagi Muslim Jembrana untuk selalu tegak, lurus, dan konsisten dalam 
meneladani akhlak Nabi Muhammad Saw. sebagai manusia termulia dan paling berbudi luhur.

Kedua, pohon pisang yang padanya ditancapkan telur saat maulid juga memiliki makna filosofi. Allah Swt. berfirman "Kami keluarkan dari tanaman yang menghijau itu butir yang banyak maka perhatikanlah buahnya di waktu pohonnya berbuah dan (perhatikan pula) kematangannya" (QS.6:99). ${ }^{30}$ Al-Qur'an kemudian menyebutkan bahwa pisang sebagai salah satu buah-buahan surga berada di antara pohon bidara yang tidak berduri dan pohon-pohon pisang yang bersusunsusun buahnya (QS.56:28-29). ${ }^{31}$ Firman ini yang menggambarkan bahwa pohon pisang dan buahnya harus dijadikan ibrah, karena memiliki khasiat dan kegunaan yang banyak. Buah pisang dapat menyehatkan usus dengan menghilangkan sembelit, selanjutnya daun pisang dapat digunakan sebagai alas, penutup, dan atau pembungkus makanan atau juga bisa dipakai sebagai payung. Daun pisang yang sudah digunakan dan mengering atau tangkai daun yang sudah kering dapat pula dimanfaatkan manusia sebagai bahan bakar atau simbol pemicu bagi bahan bakar kayu yang lebih kuat. Ini bermakna pemberi semangat bagi manusia untuk menjalani kehidupan seperti yang dialami oleh Nabi Muhammad Saw.

Ketiga, batang pisang yang dipenuhi serat-serat yang panjang dapat dimanfaatkan manusia untuk tali-temali yang dipintal, sebagian lagi digunakan sebagai pita-pita untuk bahan anyaman, juga dapat digunakan sebagai benda-benda pakai, seperti; tas, dompet, sarung bantal kursi dan lain-lain. Batang pisang yang sudah lapuk dapat dimanfaatkan sebagai penyubur tanah pertanian. Ini semua menggambarkan agar melalui tradisi male, manusia mampu menjadikan dirinya bermanfaat untuk sesamanya dan untuk makhluk lain. Pohon pisang tidak mau mati sebelum melahirkan tunas-tunasnya, artinya pohon pisang memberikan gambaran yang baik mengenai alih generasi, begitu pula jika dikontekstualisasikan dalam pergantian kepemimpinan (suksesi), 
maka pohon pisang telah mengajarkan kepada manusia agar menyiapkan kaderisasi sebagai bentuk regenerasi.

Keempat, setandan buah pisang jika diperhatikan ternyata bergantung pada ares yang berada di dalam pohon pisang. Jadi ares tersebut identik dengan isi pohon pisang. Filosofi pisang dari kacamata tafsir spiritual, ares mengisyaratkan sebagai Arsy (singgasana Allah Swt) yang identik dengan hati atau kalbu seorang Muslim yang bersih dan bening. Dalam makrifat tasawuf, hati orang mukmin yang bening bisa merupakan Arsy-nya, sebab di alam semesta ini tidak ada yang mampu menampung Allah kecuali "bersemayam" dalam bersih dan beningnya hati seorang Mukmin, sebagaimana dikabarkan dalam hadis Qudsi bahwa Allah berfirman, "Bumi dan langit-Ku tidak ada yang mampu menampung $\mathrm{Aku}$, tapi hati hamba-Ku yang berimanlah yang menampung-Ku. ${ }^{32}$ Dari sini dapat dipahami bahwa ares yang bisa menghasilkan buah pisang tempatnya di dalam pohon pisang. Untuk mendapatkan ares, maka harus membuka pohon pisangnya, melepas satu per satu kulit pada pohon pisang yang membungkus ares.

Begitu pula dengan hati manusia yang bening harus diupayakan menjadi bersih dan terbebas dari kotoran penyakit-penyakit hati atau sifat-sifat buruk dan hati seperti itulah yang menjadi tajalli-Nya Allah atau tempat bersemayam-Nya. Hati itu bagaikan Arsy (singgasana-Nya) dan dada adalah kursinya. Hal itu menunjukkan, bahwa yang dimaksud hati adalah sesuatu di balik daging sanubari. Selain itu pohon pisang juga mempunyai daun yang bisa dipakai sebagai payung atau perlindungan dari guyuran air hujan dan terik panas matahari, maksudnya adalah manusia harus dapat melindungi dan mengayomi sesama seperti diisyaratkan oleh daun pisang yang dapat melindungi segala kondisi.

Selain memiliki makna-makna edukatif-filosofis, tradisi male sebagaimana diutarakan oleh KH. Ahmad Muzakki, ${ }^{33}$ mengandung nilai-nilai luhur yang dibutuhkan dalam rangka menciptakan kehidupan yang harmonis dan humanis. Nilai-nilai luhur itu antara lain: nilai 
etika, estetika, dan nilai sosial. Implementasi dari nilai-nilai tersebut dapat dilihat dari: Pertama, nilai etika. Proses arak-arakan bertujuan untuk memberitahukan kepada khalayak ramai khususnya warga yang beragama Hindu (umat mayoritas), bahwa umat Muslim mohon izin sedang melaksanakan kegiatan peringatan hari besar keagamaan yang dalam perjalanannya tidak hanya diikuti oleh umat Muslim, tetapi umat diikuti oleh Hindu, bahkan banyak dari proses arak-arakan dikawal oleh pecalang (polisi adat Bali); Kedua, nilai estetika. Nilai estetika dalam tradisi male dapat dilihat melalui bentuk atau model male itu sendiri yang mengandung nilai seni yang tinggi. Bentuk nilai seni lainnya adalah dalam pembacaan asrakalan pada saat male itu di arak keliling kampung. Dengan menggunakan pakaian hasil akulturasi budaya Islam dan Hindu peserta pawai seolah-olah hanyut ke dalam suasana arak-arakan; Ketiga, nilai sosial. Nilai sosial yang terdapat dalam tradisi male ini adalah sebagai sarana berbagi makanan kepada masyarakat luas, baik mereka yang beragama Islam ataupun mereka yang beragama Hindu.

Uniknya, dalam tradisi ini tidak dibatasi oleh umat Muslim saja, tetapi banyak dari umat Hindu yang mengikuti prosesnya. Telur sebagai bahan utama dari male dibagikan kepada seluruh peserta Maulid Nabi dengan tanpa memandang perbedaan agama. Aktivitas seperti itu adalah bentuk nyata dari tradisi masyarakat Jembrana yang secara sadar bersamasama untuk hidup rukun dalam keberagamaan. Potret yang terjadi di Jembrana adalah wujud dalam implementasi dari strategi dakwah Islam menggunakan sarana 'urf atau kearifan lokal. Mereka sadar bahwa mereka berbeda dari segi agama, tetapi perbedaan agama bukanlah menjadi sekat atau suatu yang dapat menghalangi untuk hidup rukun bersama-sama dalam membangun peradaban atau menciptakan sebuah masyarakat madani antara umat Islam dan Hindu di Jembrana.

Jika dilihat lebih jauh, sejak masa kelahirannya, agama Islam agama telah mengalami perjumpaan (encounter) dan terlibat secara intends dengan beraneka ragam keyakinan dan agama. Terhadap adanya pluralitas tersebut, Islam memberi prinsip dasar bahwa pluralitas 
merupakan sunnatullâh. Karenanya, setiap Muslim seharusnya memanfaatkan pluralitas itu sebagai sarana untuk saling mengenal, saling belajar, dan saling berlomba untuk memperoleh kebaikan (fastabiq al-khayrat). Interaksi dan komunikasi dengan kelompok yang berbeda, hendaknya dilakukan dengan penuh penghormatan, menjunjung nilainilai kemanusiaan, dan tetap mengembangkan solidaritas kemanusiaan (ukhuwah basyariyyah). ${ }^{34}$

\section{Kesimpulan}

Penelitian menyimpulkan beberapa hal sebagai berikut. Pertama, kendati tradisi male pada awalnya merupakan tradisi yang berasal dari umat Islam, tetapi memiliki dampak sosial yang dirasakan juga oleh Hindu, sehingga kedua umat beragam ini dengan senang hati melakukan aktivitas tradisi male sebagai bentuk dari proses komplementasi antar umat beragama; Kedua, adanya proses penanaman karakter melalui kearifan lokal dalam tradisi male. Hasil dari aktivitas ini adalah terciptanya karakter individu masyarakat Jembrana yang toleran, humanis, dan pluralis antar umat Hindu dan Muslim; Ketiga, adanya kegiatan atau aktivitas masyarakat yang dapat menumbuhkan rasa untuk saling memperhatikan dan memahami sehingga terbangun karakter individu, meliputi pengetahuan (moral knowing), perasaan (moral feeling), dan tindakan (moral action) sebagaimana yang diungkapkan oleh Thomas Lickona.

Dengan terus ditumbuh-kembangkannya tradisi male ini, masyarakat Jembrana merasa tidak ada perbedaan dalam berinteraksi sosial. Yang membedakan di antara mereka hanya agama saja. Tetapi melaui aktivitas ini perbedaan agama diantara mereka tidak menjadi jurang pemisah dalam berinteraksi dan hidup bersama ditengah-tengah masyarakat yang berdampak pada banyaknya umat Hindu yang ingin mengenal Islam lebih dalam lagi.

Penelitian merekomendasikan pentingnya memikirkan kembali sebuah strategi dakwah melalui 'urf atau kearifan lokal, setidaknya 
terkait dengan relasinya antra Muslim dan non-Muslim, bahkan untuk umat beragama di Indonesia secara keseluruhan. Karena, sebenarnya, akar masalah dari konflik sosial bisa jadi disebabkan dari ketidaktahuan setiap individu di masyarakat akan pentingnya manfaat dari kearifan lokal. Manfaat yang dapat diambil dari strategi dakwah melalui kearifan lokal adalah selain menanamkan kembali atau mempertajam pandangan hidup satu masyarakat, melalui strategi dakwah ini terciptanya subuah proses asosiasi, Integrasi, komplementasi, dan sublimasi yang kuat ditengah-tengah masyarakat yang multikultural. 


\section{Daftar Pustaka}

Al-'Ashmawi, M. Sa'id, Jawhar al-Islam, Beirut: al-Intishar al-'Arabi, 2004. Azra, Azyumardi, "Bali and Southeast Asian Islam: Debunking the Myths" dalam Kumar Ramakrishna dan See Seng Tan, eds., After Bali: The Threat of Terrorism in Southeast Asia, Singapore: World Scientific Publishing Co. Pte. Ltd, 2003.

Azra, Ayumardi, Pendidikan Multikultural: Membangun Kembali Indonesia Bhinneka Tunggal Ika. Jakarta: Republika, 2003.

Al-'Ashmawi, M. Sa'id, Jawhar al-Islam. Beirut: al-Intishar al-'Arabi, 2004. Al-Qarafî, Syihâb al-Dîn, Anwâr al-Burûq fì Anwâa' al-Furûq, Vol 3, Kairo: Dar al-Kutub al-'Arabiyyah, $1344 \mathrm{H}$.

Bailey, K. D., Methods of Social Research. New York: A Division of Macmillan Publishing Co. Inc, 2982.

Biklen, R. B. dan S. K., Qualitative Research for Education: An Introduction to Theory and Methods. Boston: Allyn and Bacon, 1998.

Chaer, M. T., "Islam dan Pendidikan Cinta Damai", ISTAWA, Vol. 2, No 1, 2016.

Damanhuri, A., Sekilas Pandang Perkembangan Umat Islam di Kabupaten Dati II Jembrana. Jembrana, 1995.

Diab, Ashadi L., "Dinamika Pemikiran Hukum Islam Di Indonesia dan Tantangannya," Jurnal Al-'Adl, Vol. 8, No. 2 Juli 2015.

Egan, K., Getting it Wrong from the Beginning Our Progressivist Inheritance from Herbert Spancer, John Dewey, and Jean Peaget. Binghamtom: Vail Ballou, 2002.

Guba, Y. S. L. dan E. G., Naturalistic Inquiry. Newbury Park: SAGE, 1985. Henninger, Joseph, "Pre-Islamic Bedouin Religion," dalam Marlyn L. 
Swartz (ed. \& trans.) Studies on Islam, New York: Oxford University Press, 1981.

Hubermen, M. M. \& M., Analisis data Kualitatif. Jakarta: Universitas Indonesia, 1982.

Idris, S., Demokrasi dan Filsafat Pendidikan. Banda Aceh: Ar-Raniry Press, 2014.

Indagosa, I. B., Sejarah Terbentuknya Kabupaten Jembrana. Negara, 2000.

Islam, A. S. dan M. A. M., “Beberapa Aspek Kodikologi Naskah Keagamaan Islam di Bali”, Lektur Keagamaan, Vol 7, No. 1, 2009.

Karim, M. A., “Toleransi Umat Beragama di Desa Loloan, Jembrana, Bali" Analisis, XVI, No1, 2016.

Machali, I., "Peace Education dan Deradikalisasi Agama", Jurnal Pendidikan Islam, Vol 2, No 1, 2016.

Mashad, D., "Muslim Bali”, Mencari Kembali Harmoni yang hilang. Jakarta: Pustaka Al-Kautsar, 2014.

Meredith D. Gall, Joyce P. Gall, \& W. R. B., Educational Research: An Introduction, 7th eds. Boston: Pearson Education, Inc, 2013.

Merriam, S. B., Qualitative Research: A Guide to Design and Implementation (USA). The Jossey-Bass, 2009.

Mulyana, D., Metodologi Penelitian Kualitatif: Paradigma Baru Ilmu Komunikasi dan Ilmu Sosial Lainnya. Bandung: Remaja Rosdakarya, 2002.

Peters, F.E., Mohammad and the Origin of Islam, New York: State University of New York State, 1995.

Saidi, S. Sejarah Keberadaan Umat Islam di Bali. Denpasar, 2002.

Saputra, R. R. H., Berfikir Supra Rasional. Jakarta: Republika, 2016.

SJ,Mudji Sutrisno, Membaca Rupa Wajah Kebudayaan. Yogyakarta: Kanisius, 2014. 
Stetsenko, A.,(2011). From relational ontology to transformative activist stance on development and learning: expanding Vygotsky's (CHAT) project. Springer, Vol. 6, No. 7, 2011.

Sumarsono, Pemerintahan Bahasa Melayu Loloan di Bali. Universitas Indonesia, 1990.

Sumiati, D., "Intercultural Communication Based on Local Wisdom That Made the People of Bali Reject Sharia Tourism", Asian Journal of Media and Communication, Vol. 1, No. 2, 2017.

Suprapto, "Islam, Pluralitas, dan Kerukunan Antar-Agama Perspektif Interdisciplinary Studies", Mimbar, Jurnal Agama dan Budaya, Vol. 28, No. 1, 2011.

Syam, M. N., Filsafat pendidikan dan dasar filsafat pendidikan pancasila. Surabaya: Usaha Nasional, 1984.

Varshney, A., Ethnic Conflict and civic life: Hindu and Muslim in India. New Haven and London: Yale University Press, 2002.

Watt, Montgomery, Muhammad, Prophet and Statesman, New York: Oxford University Press, 1961. 


\section{Endnotes}

1. Lihat Syihâb al-Dîn al-Qarafî, Anwâr al-Burûq fî Anwấ' al-Furûq, Vol 3, Kairo: Dar al-Kutub al-'Arabiyyah, 1344 H, h. 49.

2. Lihat F.E. Peters, Mohammad and the Origin of Islam, New York: State University of New York State, 1995, h. 105. Lihat juga Joseph Henninger, "Pre-Islamic Bedouin Religion," dalam Marlyn L. Swartz (ed. \& trans.) Studies on Islam, New York: Oxford University Press, 1981, h, 15. Bahkan Watt berkesimpulan bahwa Nabi Muhammad mendapatkan pengetahuan tentang konsepkonsep Biblikal secara umum dari lingkungan intelektualnya di Mekkah. Lihat Montgomery Watt, Muhammad, Prophet and Statesman, New York: Oxford University Press, 1961, h. 41.

3. Azyumardi Azra, Reposisi Hubungan Agama dan Negara: Merajut Kerukunan Antarumat. Jakarta: Kompas, 2002, h. 209.

4. Ashadi L. Diab, “Dinamika Pemikiran Hukum Islam Di Indonesia dan Tantangannya," Jurnal Al-'Adl, Vol. 8 No. 2 (Juli 2015), h. 51.

5. F. Nasir, N., Integrasi dan Konflik dalam Adat Pertanian Masyarakat Aceh, Bandung: Gunung Djati Press, 1999, h. 82.

6. Mudji Sutrisno SJ., Membaca Rupa Wajah Kebudayaan, Yogyakarta: Kanisius, 2014, h. 118.

7. M. Sa'id al-'Ashmawi, Jawhar al-Islam, Beirut: al-Intishar al-'Arabi, 2004, h. 28.

8. M. Sa'id al-'Ashmawi. Jawhar al-Islam, Hlm. 29.

9. Wawancara dengan Asmari, tanggal 7 April 2019.

10. W. A. Surasmi, Menggugah Kesadaran Guru dalam Kearifan Lokal pada Era Globalisasi. Surabaya: Cinta Media, 2012, h. 8.

11. Azyumardi Azra, Pendidikan Multikultural: Membangun Kembali Indonesia Bhinneka Tunggal Ika. Jakarta: Republika, 2003, h 9. 
12. Kennet D. Bailey, Methods of Social Research. New York: A Division of Macmillan Publishing Co. Inc, 1982, h. 254.

13. Sharan B. Merriam, Qualitative Research: A Guide to Design and Implementation. (USA). The Jossey-Bass, 2009, h. 13-14.

14. Gall D Meredith and other, Educational Research: An Introduction, 7th eds. Boston: Pearson Education, Inc, 2003, h. 25.

15. Lincon Yvonna S. Guba and Egon G., Naturalistic Inquiry. Newbury Park: SAGE, 1985, h. 37.

16. Robert Bogdan Biklen dan Sari Knopp, Qualitative Research for Education: An Introduction to Theory and Methods. Boston: Allyn and Bacon, 1998, h. 54.

17. Lincon Yvonna S. Guba and Egon G., Naturalistic Inquiry, h. 356.

18. Dedi Mulyana, Metodologi Penelitian Kualitatif: Paradigma Baru Ilmu Komunikasi dan Ilmu Sosial Lainnya. Bandung: Remaja Rosdakarya, 2002, h. 183.

19. Milles M. Hubermen and dan Michael, Analisis data Kualitatif. Jakarta: Universitas Indonesia, 1992, h. 92.

20. Data BPS Kabupaten Jembrana Tahun 2015.

21. Dhurorudin Mashad, "Muslim Bali", Mencari Kembali Harmoni yang hilang. Jakarta: Pustaka Al-Kautsar, 2014, h. 151.

22. Wawancara dengan Ida Bagus Komang Santika Putra, Tanggal 7 April 2019.

23. Asep Saefullah dan M. Adib Misbahul Islam, "Beberapa Aspek Kodikologi Naskah Keagamaan Islam di Bali”. Lektur Keagamaan, 7, 1, 2009, h. 53-90.

24. Ahmad Damanhuri, Sekilas Pandang Perkembangan Umat Islam di Kabupaten Dati II Jembrana. Jembrana, 1995, h. 20.

25. Azyumardi Azra, "Bali and Southeast Asian Islam: Debunking the Myths" dalam Kumar Ramakrishna dan See Seng Tan, eds., After Bali: The Threat of Terrorism in Southeast Asia, Singapore: World Scientific Publishing Co. Pte. Ltd, 2003, h. 45.

26. Wawancara dengan KH. Sya'rani Yasin, tanggal 9 Juni 2019.

27. Dalam sebuah hadits disebutkan, "siapa yang mencintaiku, maka dia 
bersamaku kelak di Surga". (HR.al-Turmuzi).

28. M. Abdul Karim, “Toleransi Umat Beragama di Desa Loloan, Jembrana, Bali" Analisis, XVI, No.1, 2016, h. 1-30.

29. Wawancara dengan Rifqil Halim, tanggal 4 Juni 2019.

30. QS. [6]: 99.

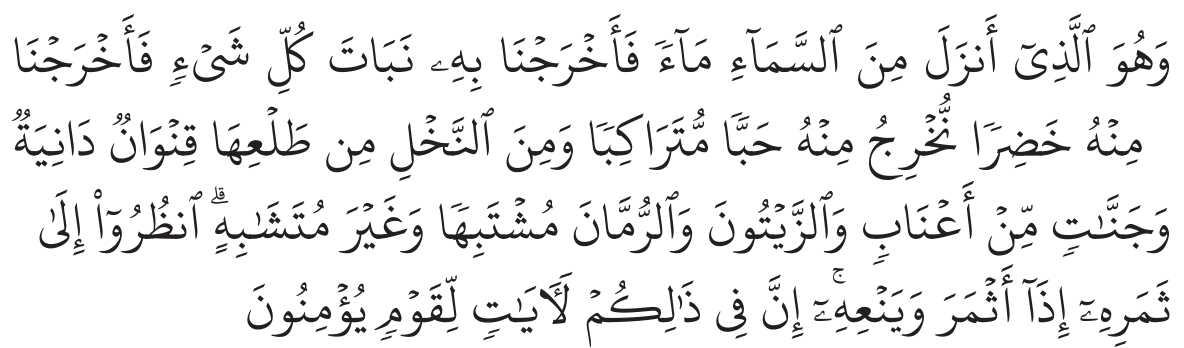

Dan Dialah yang menurunkan air hujan dari langit, lalu Kami tumbuhkan dengan air itu segala macam tumbuh-tumbuhan maka Kami keluarkan dari tumbuhtumbuhan itu tanaman yang menghijau. Kami keluarkan dari tanaman yang menghijau itu butir yang banyak; dan dari mayang korma mengurai tangkaitangkai yang menjulai, dan kebun-kebun anggur, dan (Kami keluarkan pula) zaitun dan delima yang serupa dan yang tidak serupa. Perhatikanlah buahnya di waktu pohonnya berbuah dan (perhatikan pulalah) kematangannya. Sesungguhnya pada yang demikian itu ada tanda-tanda (kekuasaan Allah) bagi orang-orang yang beriman.

31. QS. [56]:28-29.

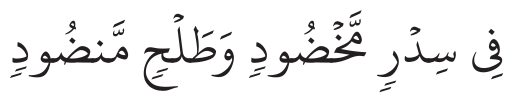

"Berada di antara pohon bidara yang tak berduri, dan pohon pisang yang bersusun-susun (buahnya)."

32. Hadits Qudsi Bab Iman.

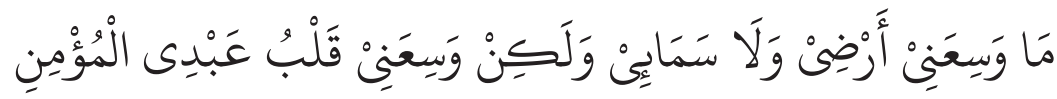

"Tidak dapat menampung-Ku (rahasia keluhuran Allah) bumi-Ku atau langit-Ku, akan tetapi mampu menampung-Ku hati hamba-Ku yang beriman." 
33. Wawancara dengan KH. Ahmad Muzakki, tanggal 4 Juni 2019.

34. Suprapto, "Islam, Pluralitas, dan Kerukunan Antar-Agama Perspektif Interdisciplinary Studies", Mimbar, Jurnal Agama dan Budaya, 28, 1, 2009, h. 49-66. 